\title{
Gender Regimes and Classical Greek Antiquity in the Fifth and Fourth Centuries BC
}

\author{
Violaine Sebillotte Cuchet
}

\begin{abstract}
What emerges when one takes a rapid look back at forty years of women's history and the history of gender in classical studies? On the one hand, there were the feminist historians who were committed to the women's liberation movements of the 1970s and were the bearers of a historiographical revolution in France. ${ }^{1}$ In Histoire des femmes en Occident, edited by George Duby and Michelle Perrot-with contributions from Christiane Klapisch-Zuber on the Middle Ages, Arlette Farge and Natalie Zemon Davis on the modern period, Geneviève Fraisse on the nineteenth century, and Françoise Thébaud on the twentieth century ${ }^{2}-$, Pauline Schmitt Pantel, an expert on the Greek world, initiated and developed this field of research with regard to antiquity. ${ }^{3}$ Since this was the first time "male and female had ever been taken into equal account in historical analysis," the questions immediately focused on "relations between the sexes." 4 The field therefore challenged experts
\end{abstract}

\footnotetext{
This article was translated from the French by Melanie Moore, revised by Violaine Sebillotte Cuchet, and edited by Nicolas Barreyre, Angela Krieger, and Stephen Sawyer. 1. See the accounts collected in Françoise Bach et al., eds., Vingt-cinq ans d'études féministes. L'expérience Jussieu (Paris: Publications universitaires Denis-Diderot-Paris 7, 2001). 2. Georges Duby and Michelle Perrot, eds., Histoire des femmes en Occident, 5 vols. (Paris: Perrin, 1990-1992; repr. 2002).

3. Pauline Schmitt Pantel, La cité au banquet. Histoire des repas publics dans les cités grecques (Diss., École française de Rome, 1992; republished with a new introduction in 2011). Her work in the area of cultural and political history continues in Hommes illustres. Mours et politique à Athènes au Ve siècle (Paris: Aubier, 2009).

4. Pauline Schmitt Pantel, "La différence des sexes. Histoire, anthropologie et cité grecque dans les années 1980," in Aithra et Pandora. Femmes, genre et cité dans la Grèce antique (Paris: L'Harmattan, 2009), 27.
} 
on the "female condition" by refusing to view women as a specific category for separate study. ${ }^{5}$ Rather, this field was absorbed into what was very much a maledominated analysis, of which the variations throughout history had to be acknowledged. ${ }^{6}$ On the other hand, gay activists and (to a lesser extent) lesbians led the epistemological revolution in the history of sexuality and, more broadly, in the history of constituting a personal identity-particularly the psychological aspectwith regard to erotic and sexual practices. Here, the place occupied by antiquity in Michel Foucault's thinking, his dialogues with Romanist Paul Veyne or his reading of Kenneth James Dover's works about what was then called Greek homosexuality should not be forgotten. ${ }^{7}$ Lastly, the linguistic turn-also regarded as a revolution in hermeneutics that affected all the social sciences in the 1980s-was further championed by another eminent Hellenist, Nicole Loraux. Her collection La Grèce au féminin focuses on what has traditionally been called women's history. More than any of her works, it provides a convincing rejection of social history. Indeed, Loraux introduces the book by stressing the impossibility of writing a history of women for anyone examining a discourse produced by men and thereby justifies her choice to write about the feminine, which is "a construct." 8

5. For example, Pieter Herfst, Le travail de la femme dans la Grèce ancienne (New York: Arno Press, 1922; repr. 1979), remains a useful source of information.

6. Georges Duby and Michelle Perrot, "Écrire l'histoire des femmes," in Histoire des femmes en Occident, vol. I, L'Antiquité, eds. Georges Duby and Michelle Perrot (Paris: Perrin, 1990-1992; repr. 2002) 8-18. Georges Duby and Michelle Perrot write: "We shall acknowledge the existence of male domination-and therefore of female subordination and subjection-as far as the eye can see in history ... This male domination comes in a great many forms. These forms are what matter to us." They conclude: "This history aims to be the history of relations between the sexes rather than the history of women." A similar approach is developed in German-language historiography by Beate WagnerHasel and Thomas Späth, "Neue Fragen an ein altes Thema: Frauen- und Geschlechtergeschichte in den Altertumswissenschaften," in Frauenwelten in der Antike. Geschlechterordnung und weibliche Lebenspraxis, eds. Beate Wagner-Hasel and Thomas Späth (Stuttgart: J. B. Metzler, 2006), IX-XXVI, particularly p. XXI.

7. Kenneth J. Dover, Greek Homosexuality (New York: Vintage Books, 1978); Michel Foucault, L'Histoire de la sexualité, vol. II, L'usage des plaisirs (Paris: Gallimard, 1984). Paul Veyne writes: "Love in itself had not yet become a sin but was a pleasure to partake in, with rules governing its use and abuse." Paul Veyne also writes in L'élégie érotique romaine. L'amour, la poésie et l'Occident (Paris: Éd. du Seuil, 1983), 179. Veyne's statement recalls the works of Michel Foucault and the title of volume 2 of L'Histoire de la sexualité.

8. Nicole Loraux, "De quelques illustres inconnues," in La Grèce au féminin, ed. Nicole Loraux (Paris: Les Belles Lettres, 2003), XVI. This work was originally published in Italian in 1993 under the title Grecia al femminile. Pauline Schmitt Pantel shares the same opinion: "The corollary of this male gaze is the dearth of specific information about the lives of women and the special focus given to representations." Pauline Schmitt Pantel, "Un fil d'Ariane," in Histoire des femmes en Occident, I:25. See also Giampiera Arrigoni, "Le donne dei 'margini' e le donne 'speciali,"” in Le donne in Grecia, ed. Giampiera Arrigoni (Rome: Laterza, 1985; repr. 2008), XI-XXX, particularly p. XVIII. The distinction between a history of men, which would be a social history, and a history of women, which could only depict exceptional women, is very clear from the nineteenth century onward: see Josine Blok, "Sexual Asymmetry: A Historiographical Essay," in 
As one of the researchers who has delved the most deeply into issues of gender difference-regarded as one of, if not the, most important mechanisms of social division ${ }^{9}$-Loraux's influence on political theory is well-known. ${ }^{10}$ The connections she established between such traditional disciplines of the humanities as literature or philosophy (particularly in America) ${ }^{11}$ contributed to the spread of the constructionist approach in the field of classical Greek history. The cultural history of the feminine-and sometimes the masculine_remains a major area of research to this day, particularly in Anglophone contexts. ${ }^{12}$

This rapid overview reveals that questions about women, the feminine, relations between the sexes or the political role of the gender divide have been formulated across a wide variety of registers. Documents have been examined across a divergent range of political and social perspectives. What were women's contributions to society? Were they confined to their homes doing nothing but domestic work? Were sexual relations considered the natural union of a man and a woman? Was a man no longer seen as a "man" if he loved other men? What did the difference between the sexes signify?

Introduced in France at the end of the 1980s, the term "gender" might have appeared to narrow the approach in sole favor of what is often deemed a literary perspective, frequently confused with studies of female representation. Traditional feminists, particularly those working on other periods of history, often openly criticized the politically correct use of gender, which they felt concealed the reality of male domination. ${ }^{13} \mathrm{~W}$ ith regard to classical antiquity, the concept of gender seemed

Sexual Asymmetry: Studies in Ancient Society, eds. Josine Blok and Peter Mason (Amsterdam: J. C. Gieben, 1987), 1-57.

9. Nicole Loraux, Les enfants d'Athéna. Idées athéniennes sur la citoyenneté et la division des sexes (Paris: La Découverte, 1981; repr. 1984).

10. Regarding this point of view, see the following articles on Nicole Loraux: Annick Jaulin's "L'imaginaire comme pratique politique"; Catherine Marand-Fouquet's "Ce que guerre civile veut dire"; Michèle Riot-Sarcey's "Distinguer ce qui se confond"; and Éléni Varikas's "Inscrire les expériences du genre dans le passé," all of which are included in a special issue entitled "Les voies traversières de Nicole Loraux. Une helléniste à la croisée des sciences sociales," Espaces TempsLes Cahiers 87-88 (2005). See also the essays collected in "Les femmes, le féminin et le politique après Nicole Loraux," classics@ 7 (2011): http://chs.harvard.edu/wa/pageR?tn=ArticleWrapper\&bdc=12\&mn=3369.

11. The book edited by John J. Winkler and Froma I. Zeitlin, Nothing to Do with Dionysos? Athenian Drama in its Social Context (Princeton: Princeton University Press, 1990) brings together Hellenists from both America and Paris. These exchanges were very much promoted by Nicole Loraux herself and, more broadly, by the issues studied at the Centre Louis-Gernet under the guidance of Jean-Pierre Vernant (particularly the reading of Greek vases suggested by François Lissarrague).

12. By way of example, see Dana Lacourse Munteanu et al., eds. Emotion, Genre and Gender in Classical Antiquity (London: Bristol Classical Press, 2011). The book examines the relationship between genders (masculine and feminine) and certain literary genres (such as epic poems, tragedies, comedies, and descriptions of artwork) on the basis of the expression of emotions (anger, pity, fear, etc.).

13. For an overview of this argument, see Christine Bard, "Une préférence pour l'histoire des femmes," in Le genre comme catégorie d'analyse. Sociologie, histoire, littérature, eds. Dominique Fougeyrollas-Schwebel et al. (Paris: L’Harmattan, 2003), 99-105. 
useful since it meant directly addressing the issue of male-female relations. ${ }^{14}$ In France at least, a consensus has recently been reached on the term, which everyone agrees can be interpreted differently. In what is bound to be a simplification, the social sciences distinguish between three uses of the term "gender" that I think correspond to those made by historians and experts on classical Greek societies in particular. The term indicates at once social assignment-in other words, the normative conduct of men and women-, sets of characteristics described in specific contexts as feminine or masculine, and the relative space occupied by gender difference in relationships between individuals.

While analyzing relationships between the sexes used to mean studying how male domination was exercised along with the inevitable resistance and adjustments to it, expressions of gender difference are now employed in relation to the relativity of the gender divide: "Gender difference stems from a social and cultural interpretation of the differences between the male and female body." 15 Often considered as providing a general shape to society as a whole,${ }^{16}$ gender difference has long been invariant where analyses of the historical constructs of male domination are concerned. ${ }^{17}$ If, however, one accepts that gender difference is the result of social interpretation (what societies do or do not make of it), ${ }^{18}$ it is no longer

14. Schmitt Pantel declares: "We first and foremost decided to directly address what has come down to us through ancient documents: male discourse on women and, generally speaking, the difference between the sexes, or 'gender." Schmitt Pantel, "Un fil d'Ariane," 25.

15. Sandra Boehringer and Violaine Sebillotte Cuchet, "Introduction," in Hommes et femmes dans l'Antiquité grecque et romaine. Le genre, méthode et documents, eds. Sandra Boehringer and Violaine Sebillotte Cuchet (Paris: A. Colin, 2011), 14. Sandra Boehringer, to whom I would like to express my gratitude for the rich discussions we have had, will no doubt easily identify aspects of our exchange in the ideas presented here.

16. In an innovative article written in 1982, Pauline Schmitt Pantel borrowed the term "gender difference" from Geneviève Fraisse and, defining it differently from how I currently define it, undertook research on the topic without adopting a feminist approach: "The threshold is perhaps crossed if it can be demonstrated that what I have called 'gender difference' (i.e., the existence of two different genders and the relationship between them) is a fundamental aspect of Greek society and imagination, whether one describes the impact such a social and ideological structure has on all areas of civic life or whether one turns it into a political reading within the context of the city." Schmitt Pantel, "La différence des sexes," 36-37. The research currently being conducted at UmR 8210 Anthropologie et Histoire des Mondes Antiques (ANHIMA) owes a great deal to the trail blazed by Schmitt Pantel.

17. While Paul Veyne noted the heuristic interest of invariants in history, by taking the class struggle as his example he also demonstrated its highly historical character. See Paul Veyne, L'inventaire des différences. Leçon inaugurale au Collège de France (Paris: Éd. du Seuil, 1976), 22-23 and 44.

18. As early as 1935 , anthropologist Margaret Mead wrote in her preface to Sex and Temperament in Three Primitive Societies: "In expecting simple reversals-that if an aspect of social life is not specifically sacred, it must be specifically secular; that if men are strong, women must be weak-we ignore the fact that cultures exercise far greater licence than this in selecting the possible aspects of human life which they will mini- 
possible to agree with the premise whereby an individual's sex, regardless of the context, automatically and naturally consigns her/him to a network of specific significations-her/his gender. In other words, the category of women, like the category of men, can no longer be taken for granted. It is the product of an interpretation of social distinctions (class, race, sex, age, etc.), which from the outset presumes that gender is the most fundamental defining feature. This interpretation emerges from both contemporary researchers-who, in choosing to study women or the divisions between men and women, thereby place them in homogenous categories-and the societies being studied, which in some contexts make gender difference the determining feature in organizing their social hierarchies.

No one would even consider challenging the notion that it is a political choice to think of society as equally composed of men and women and to deliberately make that diversity visible (which was what feminists in the 1970s and particularly women involved in women's history chose to do). Obviously, both male and female researchers working on gender remain committed scientists. What conclusions can be drawn from this? While it is generally accepted that the researcher's stance steers the interpretative line of her/his research, the interpretative line or stance of the documents she/he studies are not often questioned, despite being involved in a hermeneutic that may be compared to our own. There were probably just as many ways in ancient times as there are today of looking at the relationship between men and women as well as giving or not giving meaning to physical attributes, including gender. For the researcher, the task should now consist of marking the boundaries of the comparative space occupied by gender difference (i.e., distinguishing the gender regimes that belong to each socio-discursive context studied). ${ }^{19}$ The more distant the area of research is from the researcher, the easier it should be to reveal its discrepancies and variations as well as its differences from currently familiar gender regimes. From this point of view, research into ancient times, or noncontemporary periods, has a heuristic value comparable to the research done by ethnologists and anthropologists working on "exotic" societies at the beginning of the twentieth century. From this perspective, classical Greek antiquity offers a particularly interesting test laboratory since, on the one hand, society as a whole seems not to have been organized according to gender divisions and, on the other hand, analyzing this society makes it possible to grasp the socio-political issues specific to division into two genders, the adult citizen (anerr) and the wife and mother $(g u n \bar{e})$, usually translated as the Greek man and the Greek woman. In attempting to demarcate the various gender regimes, experts no longer contribute to writing a history of women or a history of men and women but to writing a history of social distinctions.

I would like to explain the ambitions of this inquiry by demonstrating that the three approaches to gender briefly outlined in this introduction all lead to the

gender was often insignificant, a fact all too often overlooked by research on the history of women and gender.

19. See the introduction by Didier Lett, "Gender Regimes in Western Societies from Antiquity to the Seventeenth Century," Annales HSS 67-3 (2012): 393-94. 
isolation of a single regime of gender favoring gender difference (i.e., the division between male and female). In subsequently focusing on three different areas of analysis, I will show that this gender regime did not structure the whole of society, which was traversed by other, far more significant divisions than that between the sexes. Finally, I shall examine one specific example in order to briefly analyze how the various approaches to making sense of gender difference can clash, providing further evidence that different gender regimes co-existed in classical Greek antiquity.

\section{Three Uses of Gender}

\section{Ideal Standards of Social Behavior}

Gender most frequently refers to the social roles of the sexes. In this sense, it denotes an imperative social norm: to behave like a man or like a woman. This standard may be established from a discursive point of view, meaning that it corresponds to what people usually say about the ideal behavior that researchers merely describe. It may also be established statistically when research seeks to understand how people usually behave on average. In the case of classical Greece, statistical research is impossible given the lack of data. What remains is the ideal standard, which, as is well known, distinguishes between the gune (the wife and mother of citizens) and the anerr (the adult male citizen). The crucial imperatives are as follows: the gune must produce legitimate children, the aner must defend the country, and both must look after the familial household, the oikos. While participating in the deliberative and judicial assemblies was a privilege afforded the aner , it was not an imperative. A citizen who supported his family and participated in the community's military effort (and sometimes also in the financial effort) and who for various reasons did not attend the assemblies, remained an anerr. A number of studies have shown how social practices, often within a ritual framework, resulted in a veritable gender habitus. ${ }^{20}$

Standards of social behavior were invoked either to honor good Athenians, male or female, or to criticize them. Aeschines's speech Against Timarchus (345) remains the standard reference for explaining the norms associated with proper masculine behavior. From the city's point of view, prostituting oneself was as bad as failing to perform military duties or discarding one's shield on the battlefield. Such misconduct was equated with refusing to support one's parents in their old age, wasting one's inheritance through extravagant living or negligence, and failing to pay one's taxes. ${ }^{21}$ This ideal standard of masculinity corresponded to self-control

20. See Pierre Brulé, La fille d'Athènes. La religion des filles à Athènes à l'époque classique: mythes, cultes et société (Paris: Les Belles Lettres, 1987). Brulé's book provides a perfect description of this habitus for Athenian women, which became part of divinelysanctioned behavior comprising the repetition of ritual gestures and acts of storytelling invoking heroines.

406 21. Aeschines, Against Timarchus 28-32. 
(the ethic of sophrōsune and kosmos), ${ }^{22}$ which in turn served another particular ethic by protecting the legitimate transfer of property and status. All forms of sexual practice were legal in Athens as long as the citizens (male or female) who shared the same desire did not belong to the neighboring oikos. ${ }^{23}$ This was particularly true for girls, since illegitimate pregnancy was obviously feared. As a result, the imperatives of ideal types of behavior related equally to boys and girls at least as long as they were members of a citizen's household.

Daniela Marchiandi's recent study of family funeral enclosures in Athens complements this analysis with archeological evidence. Initially restricted to an elite class, the custom of building family funeral periboloi developed in Athens in the fifth century, attesting to growing interest in the idea of legitimate descent and the continuity of the oikos. ${ }^{24}$ The iconography of funerary stelae reproduced the ideal division of gender roles, while epigrams stressed conformity to the ethic of the polis developed by the Attic orators. Men were presented as soldiers and, less frequently, as priests. Women were presented as wives or mothers, thereby guaranteeing the legitimate reproduction of the household and the citizen body. Young "adolescents" were either portrayed as either future soldiers or potential wives and mothers. Children propelled the oikos and the city into the future. Group scenes were important, and the sole form of interaction between the individuals in them was the handshake (dexiosis), the iconographic marker of the philia linking the contracting parties. As a symbol of group cohesion, the gesture united sometimes the couple (man and woman) and sometimes the progenitor and a son or brothers. The epigrams listed the names of the deceased and expressed the individual struggle whereby each person sought to depict her/his own dead-male or female-as the very best according to civic standards. Funerary vases in the enclosures attest to the vitality of a faith that underlined the extent to which selfexpression was incorporated into the customary rules, or nomima. Marchiandi's prosopography research shows that the population concerned by these enclosures was fairly mixed when it came to socio-political activities but was almost always involved in civic duties. This leads her to conclude that these were the people known in contemporary documents as the "epieikeis," or those who lived together in the oikos. Consequently, possessing a funeral enclosure was particularly important for Athenians. Those who had a peribolos were citizens with an opportunity to depict their oikos, which was composed of men and women, young people and children, and sometimes servants. Depending on age and gender, each one had a

22. Paul Cartledge, Paul Millet, and Sitta Von Reden, Kosmos: Essays in Order, Conflict and Community in Classical Athens (Cambridge: Cambridge University Press, 1998).

23. On the politics of sexuality, the creation of state brothels to protect the virtue of the daughters of citizens' households and the attribution of this policy to Solon, see David M. Halperin, "The Democratic Body: Prostitution and Citizenship in Classical Athens," in One Hundred Years of Homosexuality and Other Essays on Greek Love (London: Routledge, 1990). None of the sources cited predate the end of the fourth century. 
repertoire_albeit fairly limited_of markers conferring value. Gender was a fundamental factor in the distribution of these markers, making it possible to declare that a wife had been chaste and tender and a husband had been a good soldier or a good father. Nonetheless, the formation of a united group, as demonstrated by the conventional handshake or the physical reality of the peribolos, proved far more important than these internal distinctions.

From textual and archeological perspectives, there is no evidence that all men and women were equally affected by gender imperatives. The norms of the gun $\bar{e}$ and the aner did not directly copy gender difference. Rather, norms gave meaning to gender differences within the oikos and played a part in conferring value upon the household, which thereby became a good oikos. They constructed social distinctions applying to both women and men, separating the "bourgeoisie" from everyone else (to reprise the anachronistic term employed by Marchiandi), which had the advantage of specifying a more precise division than the one between citizens and non-citizens. Research into gender as social imperative therefore stresses the specificity of the gender regime constructed around the gunelaner polarity.

\section{Cultural Characteristics}

Gender is sometimes used to designate a set of physical, behavioral or cultural characteristics connoted as feminine or masculine. Thus, weakness, softness, and a taste for luxury are often associated with the feminine, while valor, endurance, and courage are associated with the masculine. Examples abound in Greek sources. Herodotus recounts the anecdote about the Lydian King Croesus who, defeated by Cyrus the Persian in the middle of the fourth century BC, advised him to reform the Lydians' morals in order to deter them from resistance and revolt: "Send, I say, and forbid them to possess weapons of war, and command them to wear tunics under their cloaks and buskins on their feet, and to teach their sons lyre-playing and song and dance and huckstering. Then, O king, you will soon see them turned to women instead of men; and then you need not fear lest they revolt." 25 Resistance to domination is masculine in gender, whereas trade, the arts, and submission to orders are feminine. ${ }^{26}$ The themes are identical in the speeches of the fourthcentury Attic Orators: if he became embroiled in conflict with another politician, the citizen who sought to exercise public duties risked being judged on the level either of his effeminacy or his masculinity. Aeschines, a rival of Demosthenes, attacked the latter's ally Timarchus by accusing him of "acting like a woman." 27 In a famous 1990 article, John Winkler analyzed another passage by Aeschines, an

25. Herodotus, The History, trans. A. D. Godley (Cambridge: Harvard University Press, 1920; rev. and repr. 1990), 1.155.

26. Like the enemy, the coward is usually described as a woman. See: Herodotus, The History 1.37, 3.134, 9.22, and 9.107; Angelos Chaniotis, War in the Hellenistic World: A Social and Cultural History (Oxford: Blackwell, 2005), 102-14. 
extract from his speech On the Embassy, in which Demosthenes is treated as a depraved man (kinaidos). ${ }^{28}$

The invective frequently linked a specifically female lexicon-sometimes involving compound words (androgunos, thelumorphos, thēludriess anēr)—with the vocabulary of tenderness/softness (malakia) ${ }^{29}$ and excess (hubris). ${ }^{30}$ Used in such a way, gender served as a rhetorical tool designed to designate the behavior of citizens and, more specifically, the behavior of those who claimed to be running the city. It had nothing to do with women.

Elsewhere, sets of masculine or feminine characteristics were neither firmly established nor rigidly organized, and most of the markers that were employed could shift from a masculine connotation to a feminine one, depending on context. Herodotus hints at this in Book 7 of his History when he describes Telines, ancestor (progonos) of Gelon and ruler of Syracuse in 481, whose power at the time surpassed that of all the Greeks. ${ }^{31}$ The narrator, who relates a local anecdote, ${ }^{32}$ alleges that Telines-originally from the island of Telos near Rhodes and linked to the founders of Gela, who were Rhodians from Lindos and Antiphemos of Crete-distinguished himself in the years following the foundation of Gela at the

28. John J. Winkler, "Laying Down the Law: The Oversight of Men's Sexual Behavior in Classical Athens," in The Constraints of Desire: The Anthropology of Sex and Gender in Ancient Greece (New York: Routledge, 1990), 45-70. Aeschines addresses Demosthenes, asking him what respectable Athenians would prefer: "ten thousand hoplites (hoplitas) like Philōn, with bodies as well-made (diakeimenous) as his and souls so disciplined (sōphronas), or thirty thousand depraved men (kinaidoi) exactly like you?" Aeschines, On the Embassy 151; translated and cited by Winkler, "Laying Down the Law," 47 (translation slightly modified by the author of this article).

29. Aeschines accused Demosthenes of cowardice before Philip of Macedon: "But if you, Demosthenes, shall be convicted of lying, let this be your penalty-to confess in this presence that you are a mere girl (androgunos) and no free man (eleutherios)." Aeschines, On the Embassy, trans. Charles D. Adams (Cambridge: Harvard University Press, 1988), 127 (translation slightly modified by the author of this article). Athenaeus, XII, provides an example, speaking of the malakia of the Medes, which is linked to wearing the stole, luxurious banqueting, and a feminine way of life (gunaikōn bion).

30. The notion of excess meant going too far and ranged from insults or visible departures from the rules of conduct in the assembly to rape or murder, typical manifestations of hubris. There is an appropriate and different response to each offence. See: Aeschines, Against Timarchus 35 and 16 (in which excess was called hubris); David Cohen, Law, Sexuality, and Society: The Enforcement of Morals in Classical Athens (Cambridge: Cambridge University Press, 1991); and David Cohen, Law, Violence, and Community in Classical Athens (Cambridge: Cambridge University Press, 1995).

31. Herodotus, The History 7.147.

32. For the way in which Herodotus composed The History and the role played by the oral traditions preserved in family or city memory, see: Simon Hornblower, "Herodotus and his Sources of Information," in Brill's Companion to Herodotus, eds. Egbert J. Bakker, Irene de Jong, and Hans van Wees (Leiden: Brill, 2002), 373-86; Sara Forsdyke, "Greek History c. 525-480 BC," in Brill's Companion to Herodotus, eds. Egbert J. Bakker, Irene de Jong, and Hans van Wees (Leiden: Brill, 2002), 520-49, particularly p. 548 (on the role of civic traditions in western Greece, which Herodotus encountered upon settling in the city of Thourioi). 
beginning of the seventh century. When the new city was wracked by conflict, he is said to have single-handedly restored harmony by bringing back exiles banished by their compatriots. ${ }^{33}$ According to Herodotus, Telines's act was a veritable feat. Moreover, Telines's reward for his actions was that the priesthood of the goddesses, a position he appears to have held at the time of conflict, became a hereditary priesthood assigned to his genos. The anecdote thus places him in the tradition of those legislators, poets or priests who acted as peacemakers and arbiters "above the fray," thereby embodying the political as a principle of the community. ${ }^{34}$ And yet Herodotus declares himself puzzled by the accounts relayed by the Greeks of Sicily: "Now the story that is told me makes me marvel that Telines should have achieved, such a feat; for I have ever supposed that such feats (erga) are not every man's performing but only such as have a stout heart (psuche agathos) and a manly strength (rhōmess andrēies); but Telines is reported by the dwellers in Sicily to have been contrariwise of a womanish and soft habit (thēludriès te kai malakōteros anēr)." 35 Indeed, in the middle of the fifth century when Herodotus edited his Histories, the vocabulary of the feminine and malakia operated in opposition to that of prowess, courage, and masculinity. Even so, the residents of the Sicilian city seem not to have noticed the paradox. To them, malakia and femininity were not entirely incompatible with courage and masculine strength. Such attributes were considered typical of the youth and beauty of exceptional beings. European Greeks used them just as frequently to describe populations arriving from Asia, including those of Greek descent. ${ }^{36}$ Elsewhere, they described wealth and might, and therefore king-like power or tyranny. In other words, the feminine connotations of these characteristics were hardly taken for granted. In fact, they were often unrelated to gender.

33. Herodotus, The History, trans. A. D. Godley (Cambridge: Harvard University Press, 1922; repr. 1982), 7.151-53. On this passage, see: Nino Luraghi, Tirannidi arcaiche in Sicilia e Magna Grecia. Da Panezio di Leontini alla caduta dei Dinomenidi (Florence: L. S. Olschki, 1994), 120-26; Silvio Cataldi, "Tradizioni e attualità nel dialogo dei messaggeri greci con Gelone," in Erodoteo e il "modello erodoteo". Formazione e trasmissione delle tradizioni storiche in Grecia, ed. Maurizio Giangiulio (Trento: Università degli studi di Trento, 2005), 123-71, particularly p. 129.

34. Compare with Solon, frag. 6 West = Aristotle, Constitution of Athens 12.2; Nicole Loraux, "Solon au milieu de la lice," Aux origines de l'hellénisme. La Crète et la Grèce. Hommages à Henri van Effenterre (Paris: Publications de la Sorbonne, 1984), 199-214. Solon also derived his authority from his closeness to a goddess-the Mother of the Olympians, or the Black Earth-, which allows for different interpretations. See: LouiseMarie L'Homme-Wéry, "Solon, libérateur d'Eleusis dans les Histoires d'Hérodote," Reoue des études grecques 107 (1994): 362-80; Fabienne Blaise, "Solon. Fragment 36 W. Pratique et fondation des normes politiques," Revue des études grecques 108 (1995): 24-37. 35. Herodotus, The History 7.153.

36. Before becoming a tyrant, Aristodemus of Cumae was both malakos and the bravest in war: see Dionysius of Halicarnassus, Roman Antiquities 7:2.4. See also Sarah E. Harrell, "Marvelous andreia: Politics, Geography, and Ethnicity in Herodotus' Histories," in Andreia: Studies in Manliness and Courage in Classical Antiquity, eds. Ralph M. Rosen and Ineke Sluiter (Leiden: Brill, 2003), 90. On pages 91-92, Harrell points out that the notion of Greek heroism allowed for the co-existence of masculine and feminine and explains the feminine characterization of Telines in terms of his eastern origins (Asia Minor). 
The anecdote told by Nicholas of Damascus in the first century AD and attributed to Ctesias, the Greek doctor at the court of the Persian King Artaxerxes in the middle of the fourth century, illustrates the fluidity of the markers attached to gender and how little they related to gender difference. For having called the rival king Nanaros the Babylonian effeminate (androgunos), the Persian Parsondes was taken prisoner and then enslaved as a high-class courtesan: "The eunuch took Parsondes, shaved his entire body except for the head, taught him what he was asked, kept him out of sunlight, washing him twice a day, softening him up and keeping him in the women's quarters as his master (despotês) had ordered. Soon after, Parsondes was a white, smooth, and woman-like (gunaikōdēs) man (anthrōpos), who sang and played the cithara more beautifully than the music-girls with whom he performed and surpassed them in beauty as well and no-one who saw him perform at one of Nanaros's dinner parties would realize that he was not a woman." 37 In this way, the Persian learned that what he had personally taken as signs of weakness (make-up, luxury, and the delights of both the table and love, which characterized the Babylonian's royal lifestyle) were perceived by his rival Nanaros as signs of royal power, the harshness of which Parsondes now experienced in full. ${ }^{38}$ The feminine (gunaikōeses) had nothing to do with women and indicated nothing about them. It was part of a set of markers-luxury, decoration, and wealth-that diminished value in the Persian's mind but enhanced it in the Babylonian's and was always a feature of men in power.

The characterization of these signs as feminine or masculine was the result of symbolic associations generated not only by the Ancients, but also by contemporary observers. Archeologists, for example, know just how difficult it can be to avoid overinterpreting funerary evidence: it is necessary to set aside contemporary ideas of masculinity and femininity when analyzing a story like that of Parsondes in order to consider the original context of the objects or markers being singled out in order to truly make sense of them. In the best cases, researchers reach their symbolic associations through documents that are contemporaneous with the material excavated, which allows them to conclude that the society being studied interpreted some objects as gender markers (e.g., the sword and banquet cup for men or the mirror and loom weights for women). ${ }^{39}$ However, specific research-such

37. Ctesias of Cnidus, The Complete Fragments, trans. Andrew Nichols (2008), The Persika, frag. 6b* (3), http://teaching.shca.ed.ac.uk/classics/persica/documents/nichols_aCTESIAS. pdf.

38. For recent analysis of this story, see: Sandra Boehringer and Violaine Sebillotte Cuchet, eds., Hommes et femmes dans l'Antiquité grecque et romaine, 64-66; Vincent Azoulay and Violaine Sebillotte Cuchet, "Sexe, genre et politique. Le vêtement comme opérateur dans les Persica de Ctésias," in Parures et artifices. Le corps exposé dans l'Antiquité, Lydie Bodiou et al. (Paris: L'Harmattan, 2011), 25-48.

39. François de Polignac, "Sexe et genre dans les rites funéraires grecs: quelques aperçus," in Pratiques funéraires et sociétés. Nouvelles approches en archéologie et en anthropologie sociale, eds. Luc Baray, Patrice Brun, and Alain Testard (Dijon: Éd. universitaires de Dijon, 2007), 349-56; Julie Delamard and Olivier Mariaud, "Le silence des tombes? Masculin et féminin en Grèce géométrique et archaïque d'après la documentation 
as that at the Pontecagnano Necropolis in Campania, which was occupied in the High Archaic Period around the seventh century BC-shows that the same items may also be markers of social standing. Banqueting accoutrements such as a finelywrought krater, metal tableware or objects linked to sacrifice may just as well be found in a woman's tomb as in a man's without there being any indication of gender transgression since the object signified membership in the local elite. ${ }^{40}$ Like the signification conferred upon words, the signification attributed to objects is valid not in general terms but only within a context that bestows meaning.

\section{Questioning the Difference Between the Sexes}

Gender corresponds to an absolutely explicit hermeneutic position when it means questioning the relevance of the gender divide. Behind this questioning, however, the more radical philosophical question of whether gender difference exists can also be discerned. ${ }^{41}$ When it comes to classical antiquity, progress in the approaches to these issues has been made largely through findings in studies devoted to sexuality. ${ }^{42}$

Beginning with the work of Kenneth Dover, studies of sexuality in antiquity have stressed the fact that it was organized not according to the gender of the involved partners but according to individual ways of managing pleasure and its attendant outlay. It is currently accepted that the division between good and bad ways of engaging in sexual relations (aphrodisein) was not primarily determined on the basis of gender. Since these were organized according to how the act was performed, whether passively or actively (i.e., by receiving or by giving pleasure, which was not necessarily reduced to the act of penetrating or being penetrated) and according to the relationship to the power of Eros (whether its effects were

archéologique funéraire," in Problèmes du genre en Grèce ancienne, eds. Violaine Sebillotte Cuchet and Nathalie Ernoult (Paris: Publications de la Sorbonne, 2007), 65-82.

40. Mariassunta Cuozzo, Reinventando la tradizione. Immaginario sociale, ideologie e rappresentazione nelle necropoli orientalizzanti di Pontecagnano (Paestum: Pandemos, 2003); Mariassunta Cuozzo, "Interpretazione delle necropoli e questioni di genere nell'archeo-

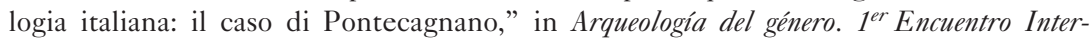
nacional en la UAM, eds. Lourdes Prados Torreira and Clara Ruiz Lopez (Madrid: UAM Ediciones, 2008), 105-38.

41. Reference may also be made to studies in the history of science. See Delphine Gardey and Ilana Löwy, eds., L'invention du naturel. Les sciences et la fabrication du féminin et du masculin (Paris: Éd. des archives contemporaines, 2000); Anne Fausto-Sterling, Sexing the Body: Gender Politics and the Construction of Sexuality (New York: Basic Books, 2000).

42. Eva Cantarella, Bisexuality in the Ancient World, trans. Cormac O Cuilleanain (New Haven: Yale University Press, 2002); Winkler, The Constraints of Desire; Halperin, One Hundred Years of Homosexuality; and Sandra Boehringer, L'homosexualité féminine dans l'Antiquité grecque et romaine (Paris: Les Belles Lettres, 2007). The following works are also relevant, even though questions about sex cede to a study of the multifaceted representations of Eros: Claude Calame, L'Éros dans la Grèce antique (Paris: Belin, 1996; repr. 2009); Florence Dupont and Thierry Éloi, L'érotisme masculin dans la Rome antique (Paris: Belin, 2001), on sexuality in the Roman world. 
suffered or elicited), ${ }^{43}$ sexuality throughout antiquity seems to have been governed primarily by the morality of self-control, which was one of the major features stressed by Michel Foucault. ${ }^{44}$ In Ancient Greece, erōs, a desire so powerful it was divine, equally and similarly governed attraction between men, between women, between men and women or between women and men, as Claude Calame and Sandra Boehringer have demonstrated. ${ }^{45}$ The various erotic attractions were subject to the same judgments of self-control that applied to the full realm of desire and pleasure. Though it is generally true that women were reputed to lack this self-control and experience far more intense pleasure than men, ${ }^{46}$ this was also characteristic of certain men, such as kinaidoi-a term that can be roughly translated as depraved (social "deviants") —and adulterers (moichoi). ${ }^{47}$ A gender map of the period gradually emerges that ignores the boundaries created by gender identity (men and women). Men and women who controlled their desires (subject to various standards in accordance with their status: kata nomon) were in one group; in another were men and women deemed subject to their pleasures (again, in accordance with each person's status: para nomon). In each of these groups, whether they conformed (kata) or not (para) to the rules, desire was directed toward partners of the same sex or toward partners of the opposite sex.

Considering the findings of studies devoted to sexuality and eroticism during antiquity, particularly concerning the Greeks, historians of social and cultural history in its broadest sense cannot avoid questioning the oft-accepted premise whereby gender difference organized ancient society as a whole, which has led researchers to adopt a new stance: gender difference as such must be questioned. Beyond the field of sexuality, some people have already taken a similar route, studying as systematically as possible the treatment-differentiated or not-of men and women engaged in similar activities. ${ }^{48}$ Reframing the question makes

43. For the complexity and circulation of the active/passive categories in relations that are controlled by Eros, see Calame, L'Éros dans la Grèce antique, 31-52.

44. Michel Foucault, Histoire de la sexualité, 3 vols. (Paris: Gallimard, 1976; repr. 1984); James Davidson, "Dover, Foucault and Greek Homosexuality: Penetration and the Truth of Sex," Past and Present 170 (2001): 3-51.

45. Calame, L'Éros dans la Grèce antique; Sandra Boehringer, "La sexualité a-t-elle un passé ? De l'érôs grec à la sexualité contemporaine: questions modernes au monde antique," Recherches en Psychanalyse 10 (2010): http://recherchespsychanalyse.revues.org/ index1696.html. For relations between women and the specificity of the discourse they create, see Boehringer, L'homosexualité féminine, 91-119.

46. Hesiod, Hesiodi Theogonia; Opera et Dies; Scutum; Fragmenta Selecta, eds. Reinhold Merkelbach and Martin L. West (Oxford: Clarendon Press, 1990), frag. 275; Luc Brisson, Le mythe de Tirésias. Essai d'analyse structurale (Leiden: Brill, 1976), 12.

47. Winkler, "Laying Down the Law," 45-71.

48. While studying the representation of men and women in images of banquets, Schmitt Pantel unsurprisingly rediscovered a classic distinction between individuals according to the double criterion of status and age in works on sexuality from antiquity onward. "Hierarchy is certainly a feature at banquets," she writes, "but to my mind it separates the adult men who conduct the game from the others, young men and women." Schmitt Pantel, Aithra et Pandora, 145-57, particularly p. 157. Studying the gestures made at shrines, she observed that men and women washed, dressed, and decorated the statues 
it possible to understand the distinctions favored by the Ancients, opening up perspectives that are of interest to social history as a whole and underlining the specificity of classical antiquity, during which community membership was the organizing principle.

\section{Classical Society Was Not Organized Along Gender Lines}

Thomas Laqueur's theories offer a useful starting point for anyone working on sex and gender during antiquity. ${ }^{49}$ Despite the almost inevitable simplifications of such a synthesis, Laqueur's work has the merit of questioning the historicity of the gendercategory division and underlining the radical strangeness of pre-modern cultures in the eyes of a contemporary observer. Ancient Greece is certainly one of the premodern cultures described by Laqueur. This section will examine some examples borrowed from linguistic categories, the heroic imagination, and civic institutions.

\section{The Words to Say It With}

The Greek language offers no indication that what we refer to today as gender was at the time as fundamental a distinguishing criterion as it has become in contemporary societies. The term gender did not exist in Greek as a general category, covering what is now called gender, or genre in French-that is, the "constitutive difference between male and female in animals and plants," otherwise known as the sex organs, or between "the categories of men and women." 50 There were terms designating men as male individuals (arrēn) and women as females (thēlu). Such terms were specific to each category and rarely used symmetrically. Thus, gender was not used as an abstract criterion for differentiation like it is today. To refer to the genitals, the Greeks sometimes used the same word for men and women-often phusis or aidoia-but these words did not have the overall value of today's term "gender." Whenever one of the ancient Greek terms was employed, the speaker stated whether the reference was to the male or female organs: phusis usually meant the female genitalia, for which the Latin equivalent was natura. ${ }^{51}$

of the gods in the same way, leading her to conclude: "When clues are available, no rule or division can be discerned between men and women." Ibid., 112-22, particularly p. 121. Similarly, looking at the division of spaces, she noted that they had been too hastily divided into "masculine" and "feminine" by male and female historians alike. In a review article entitled "Shared Spaces," Pauline Schmitt Pantel lists other recent studies that also find a need to link the question of gender difference to other social characteristics, such as status in the family and/or in blood relationships: see ibid., 105-9. 49. Thomas Laqueur, Making Sex: Body and Gender from the Greeks to Freud (Cambridge: Harvard University Press, 1990).

50. These two definitions are given in the Dictionnaire Littré and remain relevant today. The third, "the handsome sex ... women," is less so: see Émile Littré, "Sexe," in Dictionnaire de la langue française (Paris: Hachette, 1873), vol. 4. 
In this respect, the opposition of both genders, considered complementary within a clearly identified polarity, does not offer the most appropriate analytical framework for studying antiquity.

On the other hand and in keeping with current usage, the Greek term genos, from which the word gender derives, did constitute an analytical category in Greek. Commonly cited, genos denoted "a category of any kind used in classification of any sort." 52 It did not share any of the modern connotations of the current term "gender": its most frequent definition, shared with the verb gignomai (to be born, to issue from), referred to all the individuals in a single kinship group. Indeed, some documents speak of the genos gunaikōn, which is often translated as "the race of women." 53 However, this phrase, with its frequently negative connotations, was used to distinguish women of a particular sort: the wives and mothers of heirs who were indispensable to a householder but whose company was not often enjoyed. The expression genos gunaikōn was therefore not opposed to the symmetrical phrase "the race of men" (i.e., men). ${ }^{54}$

While the Greeks are commonly regarded as having divided individuals into two gender categories - cold and wet for women and hot and dry for men-, it should not be assumed that this division shaped the whole of Greek thought. The notion of two major gender categories comes from Aristotle, who speaks of the Pythagoreans (philosophers based in southern Italy in the sixth and fifth centuries BC) who used a Table of Opposites to classify their observations. ${ }^{55}$ Thanks to this table, Aristotle recounts, Greek scientists perceived reality through ten pairs of opposable principles: limited/unlimited, odd/even, unity/plurality, right/left, male/ female, rest/motion, straight/crooked, light/dark, good/bad, and square/oblong. As Geoffrey Lloyd has deftly explained, these principles, which often denoted physical qualities, provided a reservoir of markers that could be used in a variety of ways. Often one element was used to add to or subtract from another, which explains the richness and diversity of the associations that could be made. He cites as an example the epic heroes who generally used both strength and cunning in their actions, thereby adding poles that were not yet considered opposites. ${ }^{56}$ The idea of presenting these principles on the basis of pairs of complementary opposites appears to have been an Aristotelian notion inasmuch as it was accompanied by the hypothesis that bringing together both poles of a pair of opposites made it possible to create a balanced unity containing equal parts dry and wet, hot and

52. Félix Bourriot, Recherches sur la nature du "génos". Étude d'histoire sociale athénienne, périodes archaïque et classique (Paris: Honoré Champion, 1976), 205-9.

53. Hesiod, Theogony 590. See also to thellu genos, or the "race of women," which Herodotus used to describe Egyptian women in The History 2.85.

54. As a category of classification, genos could refer to humanity as a whole (in opposition to the immortals: genos anthropōn) or a specific family (including men and women). Plato, The Statesman 262c-d.

55. Aristotle, Metaphysics A 5.986a 22ff; Geoffrey Ernest Richard Lloyd, Polarity and Analogy: Two Types of Argumentation in Early Greek Thought (Cambridge: Cambridge University Press, 1966), 16.

56. Ibid., 9-10. 
cold, etc. The system of multiple combinations used by the Pythagoreans was therefore abandoned in favor of a much more restricted binary system: either one or the other, hot or cold, dry or wet, balanced or unbalanced, masculine or feminine, man or woman. From this point of view, division acquired fundamental importance in that it stressed the impossibility of being simultaneously in one category and the other. This system served as the basis for observations by everyone who thought about how living things reproduced, taking mammalian reproduction as their model. It is therefore not surprising that the authors of technical treatises on embryology put the male/female division at the heart of their interpretative system and used it to explain the gender divide. ${ }^{57}$ Should this classification by scientists be seen as reflecting the only way of organizing society as a whole? Did the division of individuals according to their role in procreation predominate?

It is well known that the Greek/Barbarian binary opposite was developed in the ancient Greek world at the end of the sixth century BC and linked to the emergence of the Achaemenid Empire and its clashes, first with the Greeks of Asia Minor and then with those of the Balkan Peninsula. ${ }^{58}$ In a dialogue between Socrates and a Stranger from Athens in The Statesman, Plato criticized the Athenian claim that humanity was divided into Greeks and Barbarians by describing it as arbitrary and illogical. ${ }^{59}$ From the point of view of logic alone, he suggests retaining a single method of classification: the division of numbers into odd and even pairs, which is the only one he deems correct (kallion). This is comparable to another good method of classification, which distinguishes between men and women. The latter case contains a unity — the human race (anthrōponn genos) — that can be divided into two relatively equal parts: "A better division, more truly classified and more equal, would be made by dividing number into odd and even, and the human race (anthrōpōn genos) into male and female (arreni kai thēlei)." ${ }^{60}$ In other words, the only relevant system of classification, apart from the odd or even nature of numbers, is

57. This division was made very clear by Helen King, Hippocrate's Woman: Reading the Female Body in Ancient Greece (New York: Routledge, 1998). She does not, however, sufficiently indicate that this was only valid in treatises seeking to precisely describe how bodies work when observed in pursuit of a single goal: reproduction. For mammalian reproduction as an analogy for describing living things, see Marine Bretin-Chabrol, "Le sexe des plantes. Analogie et catégories du genre chez les agronomes romains," in Le corps dans les cultures méditerranéennes, ed. Paul Veyne (Perpignan: Presses universitaires de Perpignan, 2007), 15-28.

58. Edith Hall, Inventing the Barbarian: Greek Self-Definition Through Tragedy (Oxford: Clarendon Press, 1989); Jonathan M. Hall, Ethnic Identity in Greek Antiquity (Cambridge: Cambridge University Press, 1997); and Irad Malkin, A Small Greek World: Networks in the Ancient Mediterranean (Oxford: Oxford University Press, 2011), 5.

59. The Stranger explains that in Athens "they separate the Hellenic race (to hellēnikon genos) from all the rest as one, and to all the other races (tois allois genesin), which are countless in number and have no relation in blood or language to one another, they give the single name 'barbarian'; then because of this single name, they think it is a single species (genos).” Plato, The Statesman, trans. Harold N. Fowler, in Plato, vol. 8 (Cambridge: Harvard University Press, 1925; repr. 1990), 262d. 
said to be the one that distinguishes between genders. The comment is evident, says the Stranger, since the distinction can be seen (eidê): there are males and females in nature and particularly in the human species, easily identified by a set of physical markers of which the genitals are the clearest distinguishing feature. This division separates humanity into two clearly opposable halves. No other visible division achieves this, neither that between blond and brunette nor that between bald and hirsute. Opposing the male category (arsēn or $\operatorname{arre\overline {n}}$ ) is the female category (thēlu, probably derived from thēe $\bar{e}$, which refers to the teat). ${ }^{61}$ The distinction concerns all mammals-i.e., it is typical of animal species differentiated at the level of reproductive capacity. Nonetheless, this principle of division-the most accurate (kallion) according to the criteria of logic-was neither retained by the Athenians, who preferred the Greek/Barbarian opposition, nor by the protagonists in Plato's dialogue. Seeking to single out the anthrōponn genos (the human race) who were the only ones concerned with the skill of leadership, the latter distinguished between animals who were capable and incapable of sexual reproduction. ${ }^{62}$ The division of bodies according to reproductive capacity, which was advanced in theory as the ideal division, was of absolutely no interest whatsoever with regard to political skills. It became, so to speak, meaningless.

This example reveals the way in which societies classified individuals according to criteria they regarded as useful in terms of the goals they were pursuing. If one considers the collective imagination of classical societies, which was shaped by archaic traditions and actively displayed in representations, festivals, and civic worship, an entirely different division makes sense: the distinction between mortals and immortals.

\section{The Amazons in the Heroic Imagination and the Myth of Pandora}

The Iliad - of which philologists date the first transcribed version to approximately the eighth century and agree that the canonical version was composed in sixth century Athens-was the first document to mention the Amazons. ${ }^{63}$ This occurs on two occasions. Priam, king of Troy, speaks of a battle in which he participated long ago and in which the Amazons (amazones) were present, while Bellerophon discusses his own success in defeating them. ${ }^{64}$

61. Pierre Chantraine, Dictionnaire étymologique de la langue grecque. Histoire des mots (Paris: Klincksieck, 1968; repr. 1999).

62. Plato, The Statesman 264d-265c.

63. Pending new discoveries, no reference to the Amazons has been found in documents in Mycenaean Greek: see John Chadwick, Documents in Mycenaean Greek (Cambridge: Cambridge University Press, 1956; repr. 1973).

64. "For I, too, being their ally, was numbered among them on the day when the Amazons came, the peers of men (amazones antianeirai)," Priam tells Helen, who is identifying the Achaean heroes grouped along the walls of Troy for the elderly king. Homer, Iliad, trans. A. T. Murray (Cambridge: Harvard University Press, 1924; repr. 1988), 3.189. In Book 6, Glaucus talks of his ancestor Bellerophon, who "slew the Amazons, women the peers of men (amawones antianeras)." Ibid., 6.186. In Book 2, the tomb of Myrine, who was sometimes regarded as an Amazon, is said to be a meeting place for the Trojan army and its allies. 
While indisputably female, the Amazons were comparatively strange in a way that distinguished them from traditional heroes-Achaean or Trojan-, all of whom were male. This strangeness also brought them closer to the status of goddesses (who were referred to using a male noun, theos). ${ }^{65}$ In the epic, little use was made of this difference. Fighting alongside or against certain heroes, the Amazons were part of the heroic world and shared in its value and prestige. Their Homeric epithet antianeirai means "equivalent to andres," a term used in the epics to refer to heroes. ${ }^{66}$ In other words, in the Greek representations conveyed by the epic tradition, the great deeds and/or beauty of both female and male characters rendered them somehow more than human, which made them close to divine. In the Aethiopis - a lost epic often attributed to Arctinos of Miletus, a poet in the seventh century BC-Penthesilea, Queen of the Amazons, leads her female warriors to the aid of Priam after Hector was slain by Achilles. All that remains of this story comes from later quotations and consists of a summary attributed to Proclos, a philosopher in the fifth century $\mathrm{AD}$, who anthologized selected pieces of literature. ${ }^{67}$ In it, Penthesilea is described as a Thracian and the daughter of Ares. She dies after heroically (aristeuousan) fighting Achilles, for which the Trojans gave her funerary honors. Achilles is the next to die: killed by Paris of Troy and Apollo, he is given a grand funeral by the Achaean army. All of these events occur in the area of the Hellespont. ${ }^{68}$ In Proclos's summary, both Penthesilea and Achilles are placed on equal footing, which is perhaps underlined by mentioning Achilles's desire $(e r \bar{s} s)$ for Penthesilea and the mockery it occasioned. ${ }^{69}$

65. "He theos initially indicates a divine being, which is additionally given a feminine marker." Nicole Loraux, "Qu'est-ce qu'une déesse?" in Histoire des femmes en Occident I:36.

66. "The prefix [anti] is never used in the sense of '(fighting) against' in epic diction. The figurative use 'equivalent to' is based on the image of a pair of scales in equilibrium: what lies on one side is 'against' [anti] what lies on the other side, and is thus equivalent. The local sense of [anti] as 'opposite' is not found in Homeric epic. The closest English equivalent is thus 'equivalent to'. Things are [anti] one another if one is equivalent to the other, such as exchange, revenge, penalty. People are [anti] one another if they can be regarded as equals." Josine H. Blok, The Early Amazons: Modern and Ancient Perspectives on a Persistent Myth (Leiden: Brill, 1995), 169-70. For the heroic, not civic, value of the term aner $r$ in the epic, see Karen Bassi, "The Semantics of Manliness in Ancient Greece," in Andreia: Studies in Manliness and Courage in Classical Antiquity, eds. Ralph M. Rosen and Ineke Sluiter (Leiden: Brill, 2003), 25-58.

67. Albert Severyns, Recherches sur la Chrestomathie de Proclos (Paris: Les Belles Lettres, 1938), IX; Albert Severyns, Texte et apparat. Histoire critique d'une tradition imprimée (Bruxelles: Palais des Académies, 1962), 11-12. For the text, see Malcolm Davies, ed., "Aethiopis", in Epicorum Graecorum Fragmenta (Göttingen: Vandehoeck \& Ruprecht, 1988), 47.

68. In Book 24 of the Odyssey, which no doubt corresponds to a later version of the epic, Agamemnon's shade, awakened in the underworld, recounts the funeral of Achilles on the banks of the Hellespont (verses 80-84). An Achilleion is mentioned as a site that belonged to the Mytilenians in Herodotus, The History 5.94.

69. According to Proclos, Thersites mocked Achilles because of the erōs that connected led to a stasis (uprising) in the Achaean camp: see Proclos, Aethiopis. 
The tradition of female warriors who were as fearsome as heroes is a recurring feature of archaic representation, which endured into classical and post-classical culture. In the second century AD, Pausanias notes that there was a gravestone (mnēma) in Athens commemorating Antiope the Amazon. Recalling the different traditions surrounding the heroine, he says that at the beginning of the fifth century BC the poet Pindar recounted her capture by Theseus and Peirithous, at the same time that Hegias of Troezen - a doubtful attribution that does not appear to predate the Hellenistic period ${ }^{70}$ —allegedly encountered Theseus during Heracles's siege of 'Themiscyra, the Amazons' stronghold. Antiope fell in love with the Athenian and is said to have willingly followed him to Athens. According to Pausanias, the Athenians maintained that, when the Amazons invaded Attica, Antiope was killed by another Amazon, Mopaldia, who was subsequently killed by Theseus. Indeed, Plutarch contends that this tale explains why Molpadia has a gravestone (mnèma) in Attica. ${ }^{71}$ The Amazons were therefore invited into the Greek cities, attesting to the heroic strength that was attributed to them despite their being considered enemies. ${ }^{72}$ Their status was even more interesting in Athens, where their image was exploited for political purposes toward the end of the sixth century, coming to symbolize the Greeks' battles with the Barbarians from Asia and later the physical superiority of men over women. ${ }^{73}$ By contrast, the celebration of the Amazons in certain Greek cities of Asia Minor, which claimed them as their eponymous founders, may be interpreted-given the Attic domination of the Aegean-as the symbolic affirmation of the political independence of these cities, which were politically subject to Athens. ${ }^{74}$

70. Blok discusses this particular dating, revealing contradictions between the sources. Hegias is sometimes described as an author of the Nostoi, an epic dating back to the sixth century BC. However, the Nostoi makes no mention of the Amazons. Hegias is not referred to as the author of the Nostoi until the fourth century BC. See Blok, The Early Amazons, 151-52.

71. Pausanias, Description of Greece, book 1, Attica 2.1.

72. In the 450s, Aeschylus writes in the Eumenides about how the Aereopagus took its name from the camp set up by the Amazons when they passed through Attica, where they made a sacrifice to Ares. See Eumenides 685-90.

73. This interpretation is usually the only one retained with regard to the Amazons. It originates at the end of the sixth century in the Theseid, an epic depicting the latest Athenian Amazonomachy: the battle in Attica that enabled the victorious Athenians to claim collective glory. Plutarch was aware that this account existed: see the Life of Theseus, 28. See, for example, William Blake Tyrrell, Amazons: A Study in Athenian Mythmaking (Baltimore: The Johns Hopkins University Press, 1984; repr. 1989). For the argument about men's physical superiority, see Lysias, Funeral Oration 17-20, which elaborates on the topic of the struggle that opposes men and women, a theme already made clear in Aristophanes, Lysistrata 672-81.

74. Josine Blok, "A Tale of Many Cities: Amazons in the Mythical Past of Greek Cities in Asia Minor," in Proof and Persuasion: Essays on Authority, Objectivity, and Evidence, eds. Elizabeth Lunbeck and Shelby Marchand (Turnhout: Brepols, 1997), 81-99. Blok cites examples of when the Amazons were politically appropriated, which scarcely go further back than the end of the sixth century. On the theme of the Amazon as a symbol of resistance to Athenian domination, see Tonio Hölscher's analysis of the group of 
The world of heroes was not the same as the world of mortals. It was seen as operating both in the present through the worship of heroes and heroines-most often during funeral rites-and in the world of the past described in poetry and art. ${ }^{75}$ It served a similar function to that of the divine world with characters distinguished by their gender according to visual codes, usually related to clothing. A small perfume container (alabaster) from the end of the seventh century, which was made in Corinth and discovered on the island of Samothrace in the northern Aegean, depicts two groups confronting each other. ${ }^{76}$ The painter indicated the names of the protagonists: Areximacha, Alkinoa, and Andromeda are found on one side, and Heracles, Iolaos, and Metoitas are on the other. The accoutrements, cap, bow, and shield indicate that both sides are equipped to fight. The female warriors are wearing a long garment (peplos) tied with a broad belt and split down the side, which along with their names makes it possible to distinguish them from the heroes. Both the men and the women are depicted as fighting in the same way, and each of them is individually named. The heroic nature of some of the female fighters is further attested to by a number of bronze shield armlets that were left as votive offerings at the shrine of Zeus in Olympia at the end of the seventh and sixth centuries. One of them still bears the inscription "[Pen]," probably an abbreviation of Penthesilea. ${ }^{77}$ There is nothing in these pictures to suggest that the viewer should regard these figures of female fighters-armed as hoplites with tunics fitted at the waist-as symbols of disorder or monstrosity. The image of Heracles fighting a female character named Andromache (or Antimache)_often accompanied by her gang of peers, who were also singled out by their nameswas a very popular motif on black-figure Attic pottery beginning in $575 .{ }^{78}$

The classical imagination must be examined within the context of poetic fiction and the epic tradition. In the epic tradition, the Achaeans and the Trojans were considered heroes. They stood in contrast to the rank and file who stayed behind in the oikos: such as children, cowardly men, elderly men, and women, all

statues erected in Ephesus in the 430s: "Die Amazonen von Ephesos: ein Monument der Selbstbehauptung," in Agathos daimôn. Mythes et cultes. Études d'iconographie en l'honneur de Lilly Kahil, ed. Pascale de Linant de Bellefonds (Athens: École française d'Athènes, 2000), 205-18; "Images and Political Identity: The Case of Athens," in Democracy, Empire and the Arts in Fifth-Century Athens, eds. Deborah Boedeker and Kurt Raaflaub (Cambridge: Harvard University Press, 1998), 153-183.

75. This dual aspect of the imagination has been the focus of research done over the last ten years by Florence Dupont at Denis-Diderot University (Paris 7) and Claude Calame at the EHESS, particularly in their "Antiquité au Présent" seminar. See: Florence Dupont, L'invention de la littérature. De l'ivresse grecque au texte latin (Paris: La Découverte, 1998); Claude Calame, Le récit en Grèce ancienne. Énonciations et représentations de poètes (Paris: Belin, 1986; repr. 2000); and Emmanuelle Valette-Cagnac, La lecture à Rome. Rites et pratiques (Paris: Belin, 1997).

76. Blok, The Early Amazons, no. 7.

77. Ibid., no. 3 and no. 2; "Achilles," in Lexicon iconographicum mythologiae classicae (LIMC), vol. II, Aphrodisias-Athena (Zurich: Artemis Verlag, 1981-1999).

78. François Lissarrague and Pauline Schmitt Pantel, "Amazones entre peur et rêve," 
of whom were deemed unworthy of participating in battle and sometimes regarded as a commodity and potential objects of trade. In this system of representation, gender difference within each category appears much less important than that of status: heroes were recognized by their weaponry-not yet by their nudity-and the Amazons were included in this category of andres. While their gender was clearly identified, it was less significant than their status as warriors, which allowed them to compete with the heroes and gain recognition both as powerful figures and a source of pride for the Greek cities that received them.

When it comes to gender difference in the realm of the imagination, the decision of historians to favor the Pandora myth as the myth of woman's origin is therefore extremely biased. ${ }^{79}$ As Jean-Pierre Vernant has shown, Pandora appears in a cosmogonic and theogonic account to be the result of a lengthy process of separating mortals and immortals. ${ }^{80}$ She served as the symbol introducing the race to iron, work, suffering, daily troubles, disease, and the mortal condition. In this context, as her name signifies, she was presented as a gift from the immortals to the mortals. ${ }^{81}$ The mythic schema assumes that of the gamos (marriage), or the ritual gift of a woman by one man to another. Pandora was given with the specific intent, which is the general purpose of all epic compositions, to establish Zeus's indisputable sovereignty. Pandora, who was inextricably linked to the sovereign order of Zeus (i.e., to the customary norms framing the social life of Greek cities), could not be understood as separate from the institution of gamos, which legitimized children born of sexual union by transforming them into sons and daughters. Pandora thus served as an instrument for rendering one's lineage immortal (the only positive counterpoint to the new status of mortal), immortality being inseparable from the oikos, or legitimate household. It is only within this framework that gender difference makes sense. Pandora, claims Hesiod, was the first of the "race of women and female kind," the ancestor of the genos of gunaikōn thelluteraōn. ${ }^{82}$ In other words, she was the first gune, the adult woman who married in order to have children because she was of the race of females (thēlus). ${ }^{83}$

79. Nicole Loraux, "Sur la race des femmes et quelques-unes de ses tribus," in Les enfants d'Athéna, 78. In "Qu'est-ce qu'une déesse?" Nicole Loraux considers the comment by Jean Rudhardt, which introduces the idea that it may only concern the ancestry of "certain" women, without accepting the implications regarding the representation of gender difference. See: Jean Rudhardt, "Pandora: Hésiode et les femmes," Museum Helveticum 43 (1946): 237-39; Nicole Loraux, "Qu'est-ce qu'une déesse ?” in Histoire des femmes en Occident I:40.

80. Hesiod, Theogony 551-616; Hesiod, Works and Days 42-105. For a detailed biography see Schmitt Pantel, Aithra et Pandora, 195-215.

81. "Pandora, because all they who dwelt on Olympus gave each a gift (dōron), a plague (edōrēsan pèma) to men who eat bread." Hesiod, Works and Days, trans. Hugh G. Evelyn White, in The Homeric Hymns and Homerica (Cambridge: Harvard University Press, 1914; repr. 1982), 80-82.

82. Hesiod, Theogony, trans. Hugh G. Evelyn White, in The Homeric Hyms and Homerica (Cambridge: Harvard University Press, 1914; repr. 1982), 590.

83. See the comments by Jean Rudhardt, "Reflets de la féminité dans le miroir de la mythologie grecque," in Les dieux, le féminin, le pouvoir. Enquêtes d'un historien des religions, 
On the basis of this account, historians have often contrasted the destiny of men with that of women in stories concerning origins. Thus, they interpret myths about the origins of men-meaning males—as tending toward the civic: men were believed to directly originate from the territory of their city. As for women, historians see their origins as relating to a single myth, that of Pandora's creation, thereby linking women to the logic of artifice and the derivative, which differs from the prevailing logic concerning males. ${ }^{84}$ Because there is no connection to civic territory in Hesiod's poem, it would thus appear that the Greeks viewed the origin of Pandora-and, therefore, of woman in general-as non-political. This reasoning, however, does not take into account the discursive logic of Hesiod's poem, which has nothing to do with the narrative logic of myths recounting the founding of cities and is deliberately set outside the political realm. Furthermore, civic myths featured typical heroines native to the territory in question, such as Praxithea, daughter of Cephisus in Attica. ${ }^{85}$ As some collections of fables in the Aesopian tradition that were written during the classical era attest, women and men were sometimes considered as having been created together, shaped either by Zeus or a demiurge like Prometheus. Men and women could equally be thought to spring from heroic genealogies, notably from Deucalion and Pyrrha, the son and niece of Prometheus. ${ }^{86}$ There is therefore no reason to overstate the value of Hesiod in comparison to other cosmogonic and genealogical traditions, nor is there any reason to make him say more than he actually said: Pandora was not the ancestor of all women, meaning a general gender category (which I have already called highly anachronistic). She was the ancestor only of those who mattered to households and heirs: those designated by the Theogony as wives-and-mothers (gunaikes), a subcategory (genos) of "females (thēluterāon)."

While, at the level of the imagination, this detour via the Amazons and Pandora underscores how gender difference was irrelevant as an invariant that structured classical society as a whole, it is nonetheless essential to examine one realm in which gender division did repeatedly occur by attempting to define the political, which depended on the citizen's household (oikos). 72 and $69-71$.

84. Loraux, "Sur la race des femmes," 83-86.

85. Euripides, Erechtheus, frag. 22, v. 64.

86. Aesop, Fables; Marie-Laurence Desclos, "Les origines de l'homme dans le corpus ésopique," in Les origines de l'homme d'après Les Anciens, eds. Jean-Michel Galy and Antoine Thivel (Nice: Université de Nice-Sophia-Antipolis, 1998), 71-88. See also François Lissarrague, "Le portrait d'Ésope, une fable archéologique," in Biographie des hommes, biographie des dieux, ed. Marie-Laurence Desclos (Grenoble: Université Pierre Mendès France, 2000), 129-44. 


\section{Citizenship, the Political, and Gender Difference}

In an article published in 2004, I stressed that the appearance of young girls being sacrificed for the sake of their homeland in the narratives of tragedy or the orations of the classical era served to emphasize the importance of lineage in the city. ${ }^{87} \mathrm{In}$ the polis, young men and all citizens called to combat were told to take as their model the idealized conduct of these young girls, who were not yet married, obedient to their fathers, and ready to die for the sake of maintaining the purity of their blood, which signified their unconditional attachment to the paternal line since future marriage would lead to mixing with another line. Boys and girls from citizens' households were called upon to demonstrate similar loyalty to their lineage. For some, this was expressed in terms of the family (genos); for others, it was expressed in terms of the city (patris). From this point of view, great value was placed upon girls as the daughters of their fathers or descendants of their grandfathers-paternal or maternal—and scions of a citizen's household.

From this perspective, my own conclusion differs fairly radically from that of Loraux, who analyzed Athenian myths of indigenousness as variants of a single structure referred to as "civic myth," "representation of the city" or "civic imagination." 88 According to Loraux, this structure revealed an important argument concerning the exclusion of women from the city and even their negation. Her thesis also relies on analysis of the syntagma repeated in certain Athenian funeral orations ${ }^{89}$ whereby the city was both "mother and homeland" but, above all, "father and homeland," as stated in the works of Demosthenes. ${ }^{90}$ Inasmuch as the mother represented the territory of the city, Loraux says that the first expression signifies the ousting of the female element, or human mothers. The second expression is more explicit. Here, the mother is expelled from the parental couple, which is presented in funeral oratory as a model for thinking about the city. Accentuating the patriarchal aspect of Athenian ideology meant distancing the specter of Mother Earth, long regarded as inherent to the composition of ancient societies, particularly in the form of matriarchy. ${ }^{91}$ Loraux replaces this principle with a political operation

87. Violaine Sebillotte Cuchet, "La sexualité et le genre. Une histoire problématique pour les hellénistes. Détour par la 'virginité' des filles sacrifiées pour la patrie," Mètis, 2 (2004): 137-61.

88. Loraux, Les enfants d'Athéna, 40, 45, and 51. Nicole Loraux interprets the myths as discourses constructed and reworked on the basis of older narrative materials by a city that "processed" them so that they expressed its own "imagination," if not "fantasies." See Loraux, "L'imaginaire des autochtones," in Les enfants d'Athéna, 15. On the "work of the myth" in the city, a notion that distances myth from an overtly functionalist notion, see Loraux, "L'autochtonie : une topique athénienne," in Les enfants d'Athéna, 69-70.

89. Nicole Loraux, L'invention d'Athènes. Histoire de l'oraison funèbre dans la "cité classique" (Paris: Mouton, 1981).

90. Loraux, Les enfants d'Athéna, 66 and 119-53 (quoting Lycurgus and Demosthenes) and 130-31 (quoting Plato, Lysias, and Demosthenes).

91. Ibid., 60-61; Nicole Loraux, "Et l'on déboutera les mères," in Les expériences de Tirésias. Le féminin et l'homme grec (Paris: Gallimard, 1989), 225; and Nicole Loraux, Né de la terre, mythe et politique à Athènes (Paris: Éd. du Seuil, 1996), 128-68. 
linked to a specific discursive context (funeral orations): the feminization of political territory, to which a maternal function was attributed (generation and trophe $\bar{e}$ ). Her conclusions go even further: "In this way all aspects of imagination in the city agree in tendentiously reducing the space made for women in the polis: language denies them a name, institutions confine them to motherhood, and official representations appear to rob them even of the title of mother." ${ }^{92}$ Women were excluded from the political.

Subsequently expanding upon her analysis in various studies, Loraux regards the feminine/masculine divide as the key that makes it possible to grasp how the polis operated as a whole. The feminine, understood as otherness, was the symbol of impending conflict (stasis) and division of the ideally united body of the city. Since the political was constructed as that which enabled resolution of the conflict—healing the division—the feminine embodied its "flip side." 93 The issue of gender difference cannot be relegated to the private or family sphere. It is included in the political just as the right side of a fabric also includes its reverse. This research stresses that the social divisions running through the city and threatening its cohesion may be formulated in terms of another division, considered absolutely fundamental: that of gender difference. ${ }^{94}$

From the moment it was published, this thesis became the subject of debate and controversy. Cynthia Patterson heavily criticized it in a 1987 article. ${ }^{95}$ She very convincingly argued that the notion of citizenship is a modern one that tends to distort the debate by blithely applying categories to the ancient world that were in fact alien to it. Studies that have been subsequently conducted into the private/public or state/civil society pairings have confirmed the extent to which these concepts arose from problems linked to the history of Western societies in the nineteenth century. ${ }^{96}$ When looking at the terms employed by the Greeks and seeking to understand the notions to which they referred, membership in a community, expressed as belonging to a civic territory, becomes the focal point of the debate. Athenians referred to themselves as astoi or Attikoi, meaning members

92. Loraux, Les enfants d'Athéna, 131.

93. Loraux, Tirésias, 22.

94. "Study of the one city gave way to reflection on the gender divide and the gender divide surreptitiously introduced the city as divided." Nicole Loraux, La cité divisée. L'oubli dans la mémoire d'Athènes (Paris: Payot, 1997), 24.

95. In France, see, for example, Marcel Detienne and Giulia Sissa, La vie quotidienne des dieux grecs (Paris: Hachette, 1989), 235-36. In the United States, see Cynthia Patterson's response, "Hai Attikai: The Other Athenians," in special issue "Rescuing Creusa: New Methodological Approaches to Women in Antiquity," ed. Marilyn B. Skinner, Helios 13-2 (1987): 49-67. Recently, Anne Jacquemin expressed her puzzlement over the failure to take into account the arguments mentioned by Patterson. See Anne Jacquemin, "Un autre conte de deux cités ou... Athéniennes et fières de l'être," Ktema 30 (2005): 33738 and note 7 .

96. See Vincent Azoulay and Paulin Ismard, "Les lieux du politique dans l'Athènes classique. Entre structures institutionnelles, idéologie civique et pratiques sociales," in François de Polignac (Paris: Albin Michel, 2007), 271-309. 
of a space that is perfectly well identified, albeit imperfectly demarcated. These terms applied to both men and women. The asto $i$ constituted a birth community in the social sense. It was this community that fourth century trials said they were protecting by calling witnesses to the festivities held on the occasion of various rites to recognize new family members and ensure that no aliens had slipped in surreptitiously. ${ }^{97}$ Members of the city called themselves both politai and Athenaioi. Employed in the plural, these terms traditionally included women. From the fifth century onward, they increasingly tended to indicate only the group of people participating in the judicial and deliberative assemblies, as well as those who engaged in warfare. ${ }^{98}$ Under these circumstances, what can be said about how gender difference featured in the political domain? Was it by excluding women or by shifting roles?

Heir to a holistic and materialist perspective, the French historiographical tradition has always distanced itself from an institutional approach to the political favored by historians of antiquity, which uses modern categorization to ponder the Greek city. François de Polignac, for instance, has shown how the religious factor - the building of shrines at various locations within a territory and population movements linked to rituals based on processions-made it possible to understand the phenomenon of the city's emergence as a political community at the dawn of the archaic period. ${ }^{99}$ Pauline Schmitt Pantel, for her part, has stressed the extent to which commensality linked to sacrificial practices formed part of the political dimension in the archaic period. ${ }^{100}$ In a collective work based on a seminar on archaic Greek inscriptions in Greek cities, Henri Van Effenterre and Françoise Ruzé also emphasized specific citizenship practices. Since they did not believe this had become a separate concept, they used the expression pre-politeia. ${ }^{101}$ All researchers thus place community identity, at once concrete and diverse (with each city having rules, or nomima, of its own), above political identity. Citizenship in

97. On the civic importance of the oikos, the rites performed there, and the importance of the family in the city, see: Florence Gherchanoc, L'oikos en fête. Célébrations familiales et sociabilité en Grèce ancienne (Paris: Publications de la Sorbonne, 2012); Aurélie Damet, La septième porte. Les conflits familiaux dans l'Athènes classique (Paris: Publications de la Sorbonne, 2012).

98. "The feminine politis appears in fact to have been coined in Athens at just this time, when politēs was becoming an exclusive male term." Patterson, "Hai Attikai," 55.

99. François de Polignac, La naissance de la cité grecque. Cultes, espace et société, VIII ${ }^{e}$ VII siècles avant J.-C. (Paris: La Découverte, 1984; repr. 1995). See also Philip B. Manville, The Origins of Citizenship in Ancient Athens (Princeton: Princeton University Press, 1990). 100. Pauline Schmitt Pantel, La Cité au banquet. Histoire des repas publics dans les cités grecques (Rome: École française de Rome, 1992), 73 and 90.

101. "So, the texts highlight the importance of issues of residence, ways of making a living, personal attachment to the community and, ultimately, of services rendered. Military concerns must play their part but they underlie our texts rather than being expressed in them. All in all, this phase of pre-politeia makes the Greek city a subtle and free entity, far removed from the rigid tyranny it eventually brought to bear on its own citizens in classical times" (authors' italics). Henri van Effenterre and Françoise Ruze, eds., Nomima. Recueil d'inscriptions politiques et juridiques de l'archaïme grec (Rome: École française de Rome, 1994), 1:28. 
the modern sense emerged during the classical period, as Aristotle's famous definition in Book 3 of his Politics attests. ${ }^{102}$

Josine Blok recently returned to this debate, taking the question of women as her starting point. ${ }^{103}$ If they were included in the city (the community of astoi), what might Aristotle's definition mean? First of all, Blok argues, Aristotle was attempting to produce a definition that was highly specific because it was meant to apply to all types of Greek cities. His definition was an intellectual one that reduced practices to a denominator thought to be common to all known democracies. Aristotle said that, in practice, the Greek cities defined as citizens those individuals born to parents who were both citizens (astos) rather than just one (father or mother). Some cities occasionally demanded that parents had been citizens for two or three generations. ${ }^{104}$ In general, civic endogamy and participation in shared rituals were essential to the city's cohesion and autonomy. ${ }^{105}$ As a result, the narrow definition in Book 3 failed to take into account what was actually happening in the cities. Aristotle was aware of this and said so. Participating in the assemblies was the sole feature of political practice shared by all cities and all types of nomima. Participation was reserved for men, the politai being understood in the masculine sense. It may not, however, be regarded as the condition that allowed an individual to be designated a citizen or not. A great many people did not participate in the assemblies. In other words, an understanding of what is referred to as citizenship comes from understanding what it meant to be an astos or an aste, a male or female member of the political community. Ritual practices, whether sacred or profane, remained a fundamental part of this definition even in classical times. ${ }^{106}$

102. "What constitutes a citizen is therefore clear from these considerations: we now declare that one who has the right to participate in deliberative or judicial (archēs bouleutikess kai kritikês) office is a citizen (politês) of the state in which he has that right, and a state is a collection of such persons sufficiently numerous, speaking broadly, to secure independence of life." Aristotle, Politics, trans. H. Rackham (Cambridge: Harvard University Press, 1932; repr. 1990), 3.1 .8 (1275b).

103. Over the past few years, Josine Blok's research has been deconstructing what historians have identified as Greek citizenship (in Aristotle), which included female citizens (their levels of participation carefully differentiated). See Josine Blok, "Becoming Citizens: Some Notes on the Semantic of 'Citizen' in Archaic Greece and Classical Athens," Klio: Beiträge zur alten Geschichte 87 (2005): 7-40. See also: Josine Blok, "Definitions of Citizenship: a Proposal for Revision" (conference held at INHA Paris, France, January 11, 2011); Josine Blok "Practices of Citizenship: Descendance, Timai and Archai" (conference held at INHA Paris, France, January 25, 2011). These conferences herald the forthcoming publication of her book Citizenship, Cult and Community (Cambridge University Press). She is thus continuing a research trend that was initially committed to studying the place of women in civic worship. See also Robin Osborne, "Women and Sacrifice in Classical Greece," in Oxford Readings in Greek Religion, ed. Richard Buxton (Oxford: Oxford University Press, 2000), 294-313.

104. Aristotle, Politics 1275b17-24.

105. Aristotle, Politics 1280b15-1281a9.

106. See the posthumous collection: Robert Parker and Christiane Sourvinou-Inwood, eds., Athenian Myths and Festivals: Aglauros, Erechtheus, Plynteria, Panathenaia, Dionysia (Oxford: Oxford University Press, 2010). 
Associations of oikoi and particularly religious networks were so vibrant during the classical period that it is possible to wonder whether Cleisthenes's reforms-which were supposed to differentiate the archaic from the classical periods and, thus, the pre-political from the political-were in fact an appropriate division. ${ }^{107}$

Women were excluded from the political decision-making process and from leadership in the city of Athens because practices had developed that had to be clearly revealed rather than because of a basic structural divide. In any event, women were not excluded from the city. They were citizens because they were Athenians, which explains how they came to participate in competitions for status like Athenian men-as Marchiandi's analysis of funeral stelae shows-and intervene in warfare to save their imperiled homeland should the men fail. ${ }^{108}$

As Athenian women, they interacted differently in the community from Athenian men, which this time was due to their gender. In other words, gender difference came into play as an essential discriminating factor but one that operated within the narrow structure of the oikos. Gender difference did not create a global division in Greek thinking since the classification of individuals and the place of gender difference within these classifications varied with regard to categories of thought, imagination, fiction, and political institutions. Another approach to examining this diversity is possible, which consists of examining situations that oppose different ways of thinking about gender difference: in other words, one that examines different gender regimes.

\section{Artemisia: Positions and Conflicts}

I would like to use the case of Artemisia, who led the city of Halicarnassus at the time of the Greco-Persian Wars (probably beginning in 490 and definitely by 480), as an example of a clash between gender regimes in classical antiquity. Her intervention in the battle of Salamis in 480 was first described by Herodotus and then commented upon by Plutarch. I have already mentioned other apparently paradoxical situations in which characteristics attributed to the female and/or male differed according to the points of view expressed by individuals who all belonged to the same Greek world, broadly referring to the whole of the Mediterranean. The case of Artemisia is interesting because it was documented over a long period and illustrates the conflicting nature of gender regimes within what is usually regarded as the most traditional Greek culture. ${ }^{109}$

107. This question arises when reading Paulin Ismard, La cité des réseaux. Athènes et ses associations, VI ${ }^{e} I^{e r}$ siècle av. J.-C. (Paris: Publications de la Sorbonne, 2010).

108. David Schaps, “The Women of Greece in Wartime," Classical Philology 77-3 (1982): 193-213.

109. Another example of a clash of gender regimes is provided, although not expressed as such, by Elizabeth D. Carney, "Women and Dunasteia in Caria," American Journal of Philology 126-1 (2005): 65-91. In this instance, gender regimes are also the result of discursive regimes: historical documents on the one hand and inscriptions on the other. 
Herodotus, a poet and historian born in Halicarnassus during Artemisia's reign around $484 \mathrm{AD},{ }^{110}$ was the first to describe what he felt was an astonishing feat, worthy of citing along with the many other wonders occurring in nature and human societies. According to Herodotus, the queen's composure and intelligence allowed her to prevail over the Athenian ships that had set out to capture her. ${ }^{111}$ Herodotus mentions the queen's gender both in order to stress the unusual nature of the phenomenon (a gune heading up an expeditionary force) and explain the response of the Athenians (who were particularly irked to find themselves under attack from a woman). As a whole, however, the narrative shows that for Herodotus as a narrator, gender had no impact on the war, tactical intelligence or the credit the Persians gave their ally Artemisia. Herodotus's narration thus provides evidence of a point of view that is both Greek and dynastic, one which was probably typical of the part of the Greek world included in the Persian Empire since the second half of the sixth century. ${ }^{112}$

In contrast, Plutarch, who wrote in the context of the Roman Empire at the end of the first century AD, disputed the authenticity of the story written or reported by Herodotus. ${ }^{113} \mathrm{He}$ found it inconceivable and, above all, undignified to believe or make others believe that a woman could defeat the Athenians. According to this gentleman from Cheronea, the Athenians of the classical era were in the process of developing an exemplary civic morality, whereby men and women occupied separate spaces according to gender. Though Plutarch's heroines might have saved their homeland, families, and traditional piety, they always returned to their domestic activities as soon as their civic mission was accomplished. ${ }^{114}$ While female heroism could temporarily accommodate virility (andreia), it was most frequently associated with familial and conjugal virtue (arête). ${ }^{115}$

110. This is at least likely. See the first page of John L. Myres's book, which describes the young Herodotus seeing Artemisia's fleet upon its return from the battle of Salamis. John L. Myres, Herodotus: Father of History (Oxford: Clarendon Press, 1953).

111. Herodotus, The History 7.99 and 8.88-93.

112. For situations involving cultural interaction, especially in the city of Halicarnassus, see: Clara Talamo, "Greci e Cari a Mileto," in Il cittadino, lo straniero, il barbaro, fra integrazione ed emarginazione nell'Antichità, eds. Maria Gabriela Angeli Bertinelli and Angela Donati (Rome: Giorgio Bretschneider, 2005), 105-14; Rosalind Thomas, "Ethnicity, Genealogy, and Hellenism in Herodotus," in Ancient Perceptions of Greek Ethnicity, ed. Irad Malkin (Cambridge: Center for Hellenic Studies, 2001), 213-33.

113. Plutarch, On the Malice of Herodotus 38 (869F).

114. In this regard, Aretaphilia's behavior was exemplary. Plutarch, Virtues of Women, 257d. On Plutarch's heroines, see Pauline Schmitt Pantel, "À propos des Vertus de femmes de Plutarque," in La religion des femmes en Grèce ancienne. Mythes, cultes et société, eds. Lydie Bodiou and Véronique Mehl (Rennes: Pur, 2009); Pauline Schmitt Pantel, "Les femmes vertueuses sont-elles des héroïnes? Femmes et tyrans dans les Gunaikon Aretai de Plutarque," in Paysage et religion en Grèce antique. Mélanges offerts à Madeleine Jost, eds. Pierre Carlier and Charlotte Lerouge-Cohen (Paris: De Boccard, 2009); and Schmitt Pantel, "Femmes et héroïsme: un manque d'étoffe ?" in Aithra et Pandora, 179-92.

115. Jeremy McInerney, "Plutarch's Manly Women," in Andreia: Studies in Manliness 
Herodotus was able to describe the queen and warrior Artemisia as being in her place at the head of the city and the army despite being a woman because the discursive realm to which he belonged was radically different. As stated in the proomion, Herodotus sought to recount wondrous feats (thauma) in his History, regardless of whether they were performed by Barbarians, small cities, men or women. He sought to depict everything a traveler might find most extraordinary in the known world. ${ }^{116}$ The story of Artemisia, therefore, merely highlighted a possible reality. In certain cities in the Greek world, which were organized differently from classical Athens, women were able to gain political power and distinguish themselves in warfare without men perceiving this as shameful. Gender regimes differed, Herodotus appears to say, and none were of greater or lesser value than any other. ${ }^{117}$

If one's reasoning is based exclusively on documents drawn up in civic contexts that modeled themselves on the exemplary oikoi of classical Athens, one is bound to view an example like that of Artemisia as pure invention, designed to be interpreted metaphorically. ${ }^{118}$ Descriptions that not so long ago appeared to lie outside the historian's field can only be taken seriously when researchers realize that several gender regimes may have existed at the same time. From this perspective, current research on the queens of the Hellenistic and imperial periods, which looks at the city dynasties of the Greek world during the archaic and classical periods, is crucial. It shows that the people of the time were far more tolerant than one is often led to believe by a particular classical rhetoric of women in positions of power and men in positions of social inferiority. ${ }^{119}$

116. "What Herodotus the Halicarnassian has learnt by inquiry is here set forth: in order that so the memory of the past may not be blotted out from among men (ta genomena ex anthrōpōn) by time, and that great and marvellous deeds (erga) done by Greeks and foreigners and especially the reason why they warred against each other may not lack renown." Herodotus, The History 1.1. Herodotus's choice of the word anthrōpoi does not refer to gender identity but instead concerns all mortals a priori.

117. Some of my research on Artemisia and the tradition associated with her was presented in two articles. See: Violaine Sebillotte Cuchet, "Hérodote et Artémisia d'Halicarnasse, deux métis face à l'ordre des genres athéniens," Clio. Histoire, femmes, sociétés 27 (2008): 15-33; Violaine Sebillotte Cuchet, "La fabrique d'une héroïne au $\mathrm{V}^{\mathrm{e}}$ siècle: Hérodote et Artémise d'Halicarnasse," in La religion des femmes en Grèce ancienne. Mythes, cultes et société, eds. Lydie Bodiou and Véronique Mehl (Rennes: Pur, 2009), 19-32.

118. Rosaria V. Munson, “Artemisia in Herodotus,” Classical Antiquity 7-1 (1988): 91-106. 119. Marie Widmer, "Pourquoi reprendre le dossier des reines hellénistiques: le cas de Laodice V," in Égypte, Grèce, Rome. Les différents visages des femmes antiques, eds. Florence Bertholet, Anne Bielman Sanchez, and Regula Frei-Stolba (Bern: Peter Lang, 2008), 63-92. These studies restore the role of women in the dynasties of antiquity, frequently through the use of epigraphic sources. 
Research into gender regimes during antiquity is wholly in keeping with the studies in the field of social science that defined the scope of what are now known as gender studies. Since it is conducted by historians looking at past societies, this research seeks to stress the variety of significations attached to gender difference, which implies that from antiquity onward there have been a variety of ways of thinking about men's relations with other men, women's relations with other women, and women's relations with men. Unlike earlier trends, this research focus has abandoned the problems of male domination of women, taking instead as its prerequisite the examination of the relevance of the categories man and woman. From this perspective, it is essential that so-called male characteristics, like socalled female characteristics, vary according to discursive context, that these characteristics do not necessarily oppose one another, and that they are only rarely associated with persons of the relevant gender. From this perspective, clarification of the narrative intentions and requirements for producing each text must precede any interpretation, as it should in any undertaking by historians. The diversity of gender regimes revealed during Greek antiquity alone calls for ever more precise distinctions between the sociopolitical contexts that construct gender hierarchy and domination and those that do not, between the imagined world of the heroes and the demands of the oikos as well as between political invectives and ethnographic descriptions. Ancient historians are thereby invited to question every type of document without favoring just one perspective in the vast cultural and chronological space of the Greek-speaking Mediterranean in order to challenge a history of what is now called heterosexuality, define its frontiers and stakes, and gain a greater understanding of its historical character.

Violaine Sebillotte Cuchet Université Paris 1 Panthéon-Sorbonne / UMR 8210 ANHIMA 